\title{
Analysing the governance system for the promotion of industrial symbiosis in the Humber region, UK
}

\author{
Anne P.M. Velenturf* \\ University of Surrey
}

\begin{abstract}
Government and industry increasingly recognise the need to develop a more circular, resource efficient and bioeconomy that is less dependent on fossil resources. Industrial symbiosis, in this study interpreted as biowaste-to-resource innovation, is a proven strategy to limit carbon emissions whilst increasing resource-efficiency and business growth. However, the effects of governance on the implementation of industrial symbiosis have remained under-explored. Hence this study analysed the governance system for biowaste-to-resource innovation in the Humber region, UK. Key individuals within governmental and associated organisations were interviewed in 2014. The results revealed that, since 2012, public sector cuts and sub-national governance changes resulted in the removal of several organisations from the regional governance network, while capacity within the remaining organisations decreased in terms of connectivity within and between governing organisations, delivered governance activities, and crucial resources including people, money, and knowledge and skills to promote resource innovation. Formal governance to specifically monitor, plan and promote (bio)waste-to-resource innovation is now virtually absent in the Humber region. This study recommends strengthening the governance for biowaste-to-resource innovation by a) increasing integration and flexibility of the regulatory 'landscape' across governmental departments at all governance levels; b) building better connections between national and regional level governmental organisations as well as within the Humber region; and c) investing in knowledge and skills as well as operational capacity of regional governance actors. These recommendations should contribute to restoring the balance between regional capacity and the national ambitions to promote biowaste-to-resource innovation as part of the circular bioeconomy.
\end{abstract}

Keywords: Policy and regulation; Network governance; Industrial ecology; Resource efficiency; Biowaste-to-resource innovation; Circular and bioeconomy. 


\section{Introduction}

\section{Industrial symbiosis in the bioeconomy}

In the face of increasing resource scarcity and climate change, society urgently needs to move towards a more circular, resource efficient and bio-based economy ${ }^{1}$ that is less dependent on fossil resources (OECD, 2009; Laybourn and Morrissey, 2009; UNEP, 2011; Dobbs et al., 2011; EC, 2011a, 2011b; Lee et al., 2012; Lin et al., 2013; Finster and Hernke, 2014; Hoffman et al., 2014; IPCC, 2014; Morgan, 2014; Rowney, 2014). In the UK the development of a waste-based bioeconomy ${ }^{1}$ has been suggested as a strategy to reduce dependency on fossil and other finite resources, and constrain carbon emissions whilst generating economic benefits including increased sustainability and energy security (DEFRA and BIS, 2012; Science and Technology Select Committee, 2014; Government, 2014, 2015a; Allen et al., 2015). Simultaneously, industrial symbiosis has been recognised as a strategy to promote resource efficiency and business development whilst limiting carbon emissions (Laybourn and Morrissey, 2009; EC, 2011a). Industrial symbiosis can be described as the development of working agreements between industrial and other organisations that, through the innovative reuse, recycling or sharing of resources, lead to resource efficiency (Jensen et al., 2011). Industrial symbiosis could contribute to the development of the bioeconomy through biowaste-to-resource innovation (Figure 1) (Velenturf, 2015).

Figure 1: One kind of industrial symbiosis is biowaste-to-resource innovation which is similar to the waste-based bioeconomy, i.e. there is an overlap between industrial symbiosis and the bioeconomy (Science and Technology Select Committee, 2014; Allen et al. 2015; Velenturf, 2015)

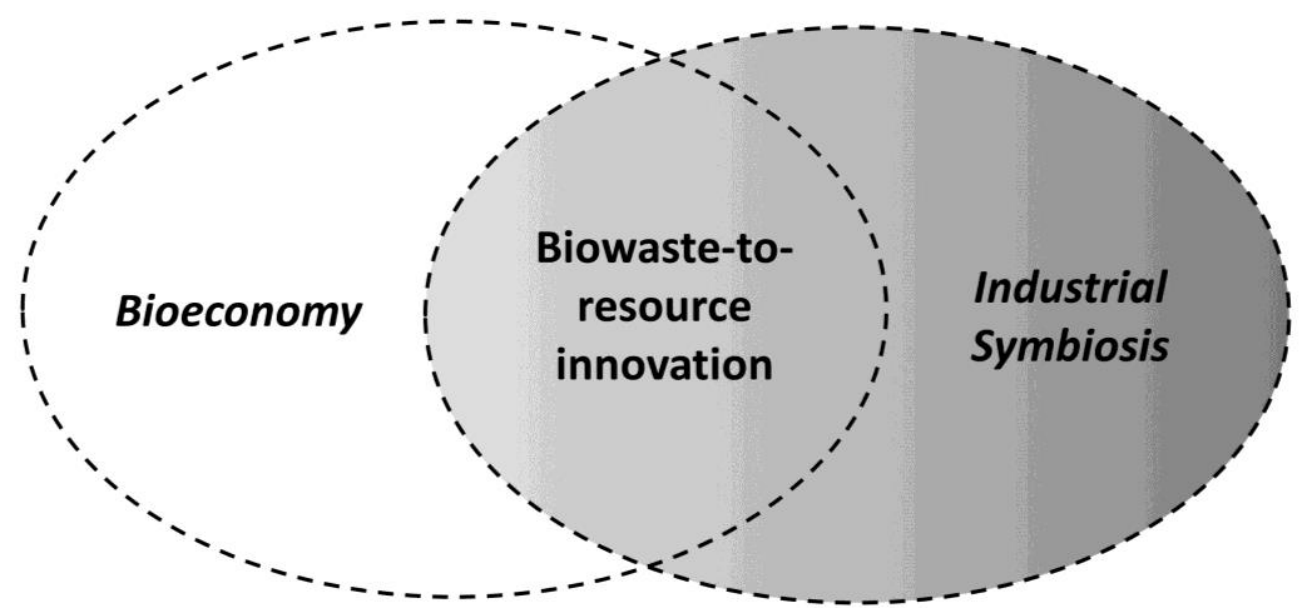

\section{Governance of industrial symbiosis}

Although the benefits of industrial symbiosis have been broadly recognised, understanding how it can be promoted by governmental organisations is limited (Velenturf and Jensen, 2015). Literature from the field suggests that successful promotion of industrial symbiosis requires a combination of top-down interventions that fit to bottom-up characteristics and processes, tailored to the context within which these innovations are to be developed (Ehrenfeld and Gertler, 1997; Desrochers, 
2004; Gibbs and Deutz, 2007; Park et al., 2008; Laybourn and Morrissey, 2009; Costa and Ferrão, 2010; Shi et al., 2010; Mathews and Tan, 2011; Christensen, 2012; Paquin and Howard-Grenville, 2012; Jensen, 2016). Although some practical insights to inform governance of industrial symbiosis have been published (e.g. Zilahy and Milton, 2008; Laybourn and Morrissey, 2009; Costa and Ferrão, 2010; Paquin and Howard-Grenville, 2012), practical instruments to support the implementation of resource efficiency policy and regulation, including measures to promote industrial symbiosis, are generally under-developed in Europe (Lehtoranta et al., 2011). Indeed, the effects of governance, particularly the actual activities of governmental organisations, on the implementation of industrial symbiosis have remained underexplored and need to be researched (Jiao and Boons, 2014; Deutz and Loppolo, 2015).

Empirical results have suggested that governmental organisations can either help or hinder in overcoming regulatory barriers during the implementation of industrial symbiosis (Velenturf, 2015; Salmi et al., 2012). In other words, the way in which policy and regulation is implemented is important for the success of industrial symbiosis (similar to findings of e.g. Bulkeley et al., 2007; Flanagan et al., 2010, 2011). Yet the challenges governmental organisations face in the implementation of industrial symbiosis have rarely been documented (an exception is Geng et al., 2010). They need the knowledge and skills to make the many small steps that eventually lead to a more resource-efficient economy in which industrial symbiosis plays a key role (Koskela et al., 2013; Lehtoranta et al., 2011). The extent of such necessary knowledge and skills within governmental organisations requires further research (also see Deutz and Frostick, 2009), in order to assess what roles and activities could reasonably be expected from them and to formulate realistic recommendations for the promotion of industrial symbiosis.

Given the limited understanding of the governance of industrial symbiosis, literature suggests that it would be sensible to facilitate learning between governmental organisations and other stakeholders whilst governing in a flexible and adaptive manner. Such governance through network steering, involving partnerships between state- and non-state stakeholders (Bulkeley et al., 2007), is reflected in systems of innovation literature. Systems of innovation consist of 1 ) institutions guiding innovation and 2) the innovation network. While systems of innovation acknowledge the role that markets play in innovation, they emphasise the importance of networks. Innovation occurs through continuous interaction between actors. Hence, bringing the right actors and relations in place, whilst ensuring the effective functioning of the network, is key to learning and innovation (Tödtling and Trippl, 2005; Chaminade and Edquist, 2005; Lundvall et al., 2002). Systems of innovation have been adopted in research on sustainable transitions. In addition to technological innovation, transitions also require changes in institutions and social practices (e.g. Geels and Schot, 2007; Bergh et al., 2011). In other words, transitions pertain to innovations that disrupt existing regimes (such as the linear and fossil-dependent economy) and instead contribute to emerging regimes (such as the growing circular bioeconomy). This focus on new disruptive industries puts transition governance in contrast to governance of innovation focused on strengthening existing industries (Alkemade et al., 2011). Industrial symbiosis can range from incremental innovations in existing industries up to more radical changes requiring regulatory changes or even the emergence of new markets, the latter showing resemblance to sustainable transitions (Velenturf, 2015; Velenturf et al., Forthcoming). These degrees of innovation may require a different governance focus, such as indicated by research on systems of innovation and sustainable transitions. However, both approaches require networks of heterogeneous actors that continuously interact during the implementation of policies in a flexible and adaptive manner (Bergh et al., 2011; Alkemade et al., 2011). Hence, similar governance structures and practices may be encountered in the exploration of governance systems for industrial symbiosis. 


\section{Empirical exploration of governance for biowaste-to-resource innovation}

This article builds on Velenturf's (2015) observations of how companies in the emerging bioenergy sector in the Humber region (UK) realised one specific type of industrial symbiosis: biowaste-to-resource innovations (Figure 1). In this study the interaction between the actors involved in the innovation process, such as the innovating company and governmental organisations, was identified as crucial. While some interactions between companies and local and regional governmental organisations worked well for the innovation at hand, others required improvement. It was suggested that knowledge of the industries, technologies, and (waste) resources within the governmental organisations played a central role in the ability to support the innovation processes. The way in which governmental organisations interacted with companies during the innovation process also proved to be important, for example in some cases interaction was perceived as extremely procedural while in other cases a more collaborative attitude was observed.

This paper builds on these findings and aims to extend understanding of the role played by local and regional governmental organisations in the Humber region in biowaste-to-resource innovations. Given the modest knowledge base for the governance of industrial symbiosis, this article presents a qualitative study analysing the governance system and exploring the following questions: 1) Who was involved in the governance; 2) What role governmental and associated organisations perceived themselves and others to play; 3) Through what activities they carried out their role; and 4) Why governance was delivered in this way. Ultimately this article aims to formulate recommendations for the governance of biowaste-to-resource innovation in the Humber region and beyond.

The next section introduces the Humber region, followed by the methods used to analyse the qualitative research gaps. Key findings are presented in "Perspectives from regional governmental organisations on the governance of biowaste-to-resource innovation". The article concludes with a discussion and recommendations for governmental organisations.

\section{Research setting: the Humber region, UK}

The Humber region is located in the northeast of England. The Humber ports (Immingham, Hull, Grimsby and Goole) form one of the busiest port complexes in Europe. The region is a mature and diverse industrial area; In addition to the welldeveloped agricultural sector, main industries include food and wood processing, chemicals, metals, fuel and power facilities (Penn et al., 2014; NOMIS, 2015; Jensen, 2016). The high concentration of industries contributes to the wider Yorkshire and Humber region being one of the largest $\mathrm{CO}_{2}$ emitters in the UK (Yorkshire and the Humber Regional Committee, 2010). Hence this area could be pivotal in achieving the UK's carbon reduction targets (Government, 2009). Indeed, the Humber region has committed itself to the expanding offshore wind sector and identified opportunities in the bioenergy sector (Humber Local Enterprise Partnership, 2014). Additionally, the Humber region has been identified as an opportunity-rich area for growth in the biochemicals sector (UKTI, 2009). Finally, significant expertise regarding the uptake of (bio)waste-to-resource innovation has accumulated in the area. The Humber region is a known case study in the literature on industrial symbiosis and resource efficiency (e.g. Mirata, 2004; Laybourn and Morrissey, 2009; Jensen et al., 2012; Wang, 2013; Velenturf, 2015). In recent years various biowaste-to-resource innovations have been adopted in this area including, for instance, industrial plants converting fatty food 
wastes into biodiesel and anaerobic digesters converting food wastes into biogas and fertiliser (Laybourn and Morrissey, 2009; Bondholders, 2014).

The region is divided into four local government authorities situated around the Humber estuary. These are the North East Lincolnshire, North Lincolnshire, Hull City, and East Riding of Yorkshire Councils. Each largely has their own planning and development agendas and goals. Rooted in the fishing industry, the north and south bank of the Humber have been competitors in the past and the respective local authorities have been reluctant to collaborate on economic development. However, the fishing industry has dwindled and both sides of the estuary have been increasingly urged to collaborate on economic regeneration. The shared estuary with its strategically important geography for port development and offshore industry is seen as key to economic growth. In 2012 the Regional Development Agency (RDA), which collaborated with the local authorities and worked on the development of the wider Yorkshire and Humber region, was dissolved. Instead, since 2012, the local authorities around the estuary, industry and various other organisations collaborate in the government-backed Humber Local Enterprise Partnership (Humber LEP).

While economic development and structural change are urgently needed, the region faces several innovation challenges. The Humber region has performed below the UK average for innovation and was characterised as an innovation follower (BIS, 2011; EU, 2012). In particular, it scored low in the uptake of environmental technologies (EU 2012). This is problematic given the central position the region aims to play in renewable energy supply, including bioenergy (Humber Local Enterprise Partnership, 2014; Bondholders, 2014). In contrast to other regions in the UK, Research and Development (R\&D) is typically carried out within companies rather than being contracted out to other facilities (BIS, 2011). Nevertheless, companies did collaborate for product and process innovation, for which knowledge was predominantly sourced within business groups or from suppliers and clients (BIS, 2011). This may adversely affect potential for (bio)waste-to-resource innovation for two known reasons. First, given that companies in the Humber region mainly trade to regional and national markets, innovation may be negatively affected as evidence suggests that companies with both local and global connections have higher innovation performance (Asheim and Isaksen, 2002; Broekel et al., 2010). Second, (bio)waste-to-resource innovations are likely to involve collaboration with a more diverse range of resource partners from previously unconnected industries (Chertow, 2000; Jensen, 2016). The National Industrial Symbiosis Programme (NISP) (Table 1) practitioners previously employed their in-depth knowledge of local businesses to develop cross-industry partnerships and promote (bio)waste-to-resource innovation (Laybourn and Morrissey, 2009; Jensen et al., 2011). However, in 2012 NISP lost governmental support for its activities in the region.

\section{Methods}

\section{Research approach}

In the introduction it was argued that governance of industrial symbiosis is still a nascent area of research (also see Velenturf and Jensen, 2015). Qualitative research gaps were outlined, including practical governance instruments and the actual activities through which industrial symbiosis is governed, understanding challenges for governmental organisations, and the knowledge and skills that they need to support industrial symbiosis. Hence this study adopted a qualitative exploratory research approach (Mason, 2002). 
The realisation of industrial symbiosis involves waste-resource suppliers and clients, technology providers, governmental organisations and various other actors who may be engaged in the innovation process (Velenturf, 2015). As a result the governance of industrial symbiosis also needs to be collaborative in nature involving state- and nonstate actors who are engaging through networks in a flexible and adaptive manner (as discussed in the introduction). Given the significance of understanding such networks, this study uses network analysis to explore how and why relations within and between governmental and associated organisations developed (Scott, 2000; Borgatti et al., 2009; Hollstein, 2011).

\section{Data collection}

During 2014, 17 interviews were carried out with individuals working in key roles within nine governmental organisations or organisations delivering tasks for/ supporting governmental organisations. Interviewees were identified through regional networking activities as well as online searches and referrals. Interviewees were selected on the basis of their job title/description and/or involvement in (biowaste-toresource) innovation in the Humber region. The interviews were carried out in an open and exploratory manner in order to gather the interviewees' accounts on a number of subjects. Interview questions had to be tailored to specific interviewees as they had different functions with often very different foci. Additionally, improvisation was necessary during the interviews, because competencies regarding biowaste-to-resource innovation, bio-based developments, or innovation in general varied from almost absent to expert level. As such, the interviews could be characterised as edging towards 'in-depth' on the continuum from structured to semi-structured and depth interviewing techniques (Jones, 2004; Bryman, 2012).

Building on Velenturf (2015), the initial plan was to focus the interviews on biowaste-to-resource innovation. However, in the engagement with potential interviewees it became clear that this focus was too narrow and it created a barrier in the recruitment of participants from some organisations. Hence the research focus was broadened to include all bio-based developments in the Humber region. This made the topic more familiar for potential participants and helped them identify and engage with the research. During the interviews, however, interviewees tended to either speak specifically about biowaste-to-resource innovation or, if this was not a particular focus in their work, about innovation and economic development in general. This was related to the interviewees' roles, which will be further explained when presenting the key findings.

The interviews revolved around three main areas of questioning:

- General description and evaluation of the interviewees' activities regarding biowaste-to-resource innovation and/or the bio-based economy.

- Network development including interaction with private and other public organisations.

- Collaborations to promote bio-based developments and biowaste-to-resource innovations.

All interviewees were assured of anonymity thus no personal names or job titles can be presented in this article. The regional governance network is relatively small and hence there is a risk of interviewees being identified through their statements. As such the use of direct quotes is also necessarily constrained in an effort to maintain interviewee anonymity. 


\section{Data preparation and analysis}

The interviews were recorded and transcribed in full before the analysis. For some interviewees and/or organisations additional transcripts were available because research participants had been interviewed previously about general drivers and barriers for industrial symbiosis in a related project (Penn et al., 2014; Schiller et al., 2014). In total 24 transcripts were available from 11 organisations (Table 1).

All data were analysed with conceptual and open codes through literal and interpretive coding strategies (Mason, 2002; Bryman, 2012). The final coding tree included codes to analyse network structure, interactions between actors, actor roles and activities, and capacity to support (biowaste-to-resource) innovations (Table 2).

The data fragments were interpreted for every code separately whilst also analysing relations between the codes. The multiple perspectives in the coded data were used to construct a valid and accurate argument (Mason, 2002). In other words, the interviewees' views on their own and on each other's governance contributions were combined through the systematic analyses of coded fragments. The coded data were organised into a logic and coherent argument to gain insights into the governance system, according to the four introduced research questions (also see Table 2). The main argument that emerged from the analysis will be presented in the next section.

Table 1: Participants in 11 organisations were interviewed. Although the table provides a brief introduction to the organisations, this study questions and analyses their roles and activities in the promotion of industrial symbiosis

\begin{tabular}{|c|c|}
\hline Environment Agency (EA) & $\begin{array}{l}\text { Delivering environmental regulation including Environmental } \\
\text { permits; Waste; Low carbon energy; Energy efficiency; and more } \\
\text { (Government, 2015d). }\end{array}$ \\
\hline $\begin{array}{l}\text { Humber Local Enterprise } \\
\text { Partnership (Humber LEP) }\end{array}$ & $\begin{array}{l}\text { The Humber LEP was formed by the four local councils around } \\
\text { the Humber estuary and it is tasked with promoting regional } \\
\text { economic development (Government, 2015c). }\end{array}$ \\
\hline North Lincolnshire Council & \multirow{4}{*}{$\begin{array}{l}\text { Local councils are responsible for a broad range of services, } \\
\text { including waste collection and recycling, planning permits, and } \\
\text { environmental safety (Government, 2015b). }\end{array}$} \\
\hline $\begin{array}{l}\text { North East Lincolnshire } \\
\text { Council }\end{array}$ & \\
\hline $\begin{array}{l}\text { East Riding of Yorkshire } \\
\text { Council }\end{array}$ & \\
\hline Hull City Council & \\
\hline $\begin{array}{l}\text { Humber Chemical Focus } \\
\text { (HCF), now HCF Catch }\end{array}$ & $\begin{array}{l}\text { Supporting process, energy, engineering and renewable } \\
\text { industries through networks, training, funding, and more - } \\
\text { collaborating with local councils, Humber LEP, EA and other } \\
\text { governmental organisations (HCF-Catch, 2015). }\end{array}$ \\
\hline University of Hull & $\begin{array}{l}\text { Delivering research and education, collaborating for knowledge } \\
\text { exchange with businesses as well as local councils, Humber LEP } \\
\text { and other governmental organisations (University of Hull, 2015). }\end{array}$ \\
\hline $\begin{array}{l}\text { National Industrial } \\
\text { Symbiosis Programme } \\
\text { (NISP) }\end{array}$ & $\begin{array}{l}\text { Identifying and delivering business development opportunities } \\
\text { through industrial symbiosis, in collaboration with businesses, } \\
\text { Regional Development Agencies, local councils, EA and others } \\
\text { (Laybourn and Clark, 2004). }\end{array}$ \\
\hline Link2Energy & Delivering NISP in the Yorkshire and Humber region up to 2012. \\
\hline $\begin{array}{l}\text { Waste and Resources } \\
\text { Action Programme (WRAP) }\end{array}$ & $\begin{array}{l}\text { Delivering research and funding whilst collaborating with } \\
\text { industries, governmental organisations and others to promote } \\
\text { resource efficiency and the circular economy (WRAP, 2015). }\end{array}$ \\
\hline
\end{tabular}


p. 153. Analysing the governance system for the promotion of industrial symbiosis in the Humber region, UK

Table 2: To answer the research questions, various conceptual and open codes were developed during the data analysis

\begin{tabular}{|c|c|c|}
\hline \multicolumn{3}{|c|}{ How was (biowaste-to-resource) innovation governed? } \\
\hline $\begin{array}{l}\text { Who were involved in } \\
\text { the governance } \\
\text { system? }\end{array}$ & $\begin{array}{l}\text { How did governmental } \\
\text { organisations carry out } \\
\text { their role? }\end{array}$ & $\begin{array}{l}\text { Why was governance delivered in this } \\
\text { way? }\end{array}$ \\
\hline $\begin{array}{l}\text { Network } \\
\text { Actors } \\
\text { Relations }\end{array}$ & \multirow{3}{*}{$\begin{array}{l}\text { Activities } \\
\text { Interaction with } \\
\text { companies } \\
\text { How initiated } \\
\text { Going well } \\
\text { Needs improvement } \\
\text { Important points } \\
\text { Interaction with } \\
\text { governmental } \\
\text { organisations } \\
\text { Internally } \\
\text { Externally } \\
\text { Collaborative culture in } \\
\text { Humber region }\end{array}$} & \multirow{3}{*}{$\begin{array}{l}\text { Available resources } \\
\text { Time (to build relations) } \\
\text { Money } \\
\text { Knowledge and skills } \\
\text { - Demonstrated } \\
\text { - Discussed bio-based developments } \\
\text { - Gaps } \\
\text { Attitude } \\
\text { Policy and Regulation } \\
\text { - Supporting } \\
\text { - Constraining } \\
\text { - Sectoral governance, Integrated } \\
\text { industrial developments } \\
\text { - Suggested improvements } \\
\text { Geography } \\
\text { Recommendations to improve Humber } \\
\text { context }\end{array}$} \\
\hline $\begin{array}{l}\text { What role did local } \\
\text { and regional } \\
\text { governmental } \\
\text { organisations } \\
\text { perceive to play? }\end{array}$ & & \\
\hline Role & & \\
\hline
\end{tabular}

\section{Perspectives from regional governmental organisations on the governance of biowaste-to-resource innovation}

In this section findings from the interviews are used to answer the four research questions posed (Table 2), explaining who were involved in the governance system, followed by a comparison of roles and activities of governmental and associated organisations, revealing mismatches that will then be linked to resources and competencies present in the region.

\section{Governance network}

While participants agreed to be interviewed about biowaste-to-resource innovations and bio-based developments, discussion mostly broadened to economic development and innovation in general. Interviewees identified organisations involved in the governance network (Figure 2) and drew attention to how this had changed over time.

Since 2012 important changes occurred in the governance structure at local and regional level. Most notably, the RDA and various associated delivery bodies were dissolved. Additionally, NISP lost public support and, although it continued to exist, the services were no longer freely available and hence were not or could not be accessed by most of the organisations in the network. Simultaneously, the Humber LEP was initiated to bring together the four local councils, businesses and various other organisations involved in the economic development of the region. The changes in the governance system, which will be further discussed throughout the results, have had 
important consequences for strategic regional resource planning and delivery of associated industrial development, as demonstrated by this quote:

(...) there's a lack of vision associated with that [investment in the economy] at the minute. There isn't one from the government, because the government structures are no longer in place to be able to say this is the vision, this is the regulation, this is the direction that we want you to go in. The direction now needs to be articulated from people like the enterprise partnerships or from the sectors to be able to say, this is what we want in the Humber, this is where we want it, and then to work with local authorities to enable that to happen. (Local council interviewee, 2014)

Figure 2: Network of governmental organisations and other organisations engaged in the governance of economic development and innovation in general, while some of these actors were also involved in bio-based developments and biowaste-to-resource innovation. Legend: Black boxes are organisations active in governance system in 2014; Silver boxes are organisations not active in governance system since 2012; Black lines are active connections; Black dotted lines are active connections since 2012; Silver dotted lines are inactive connections since 2012

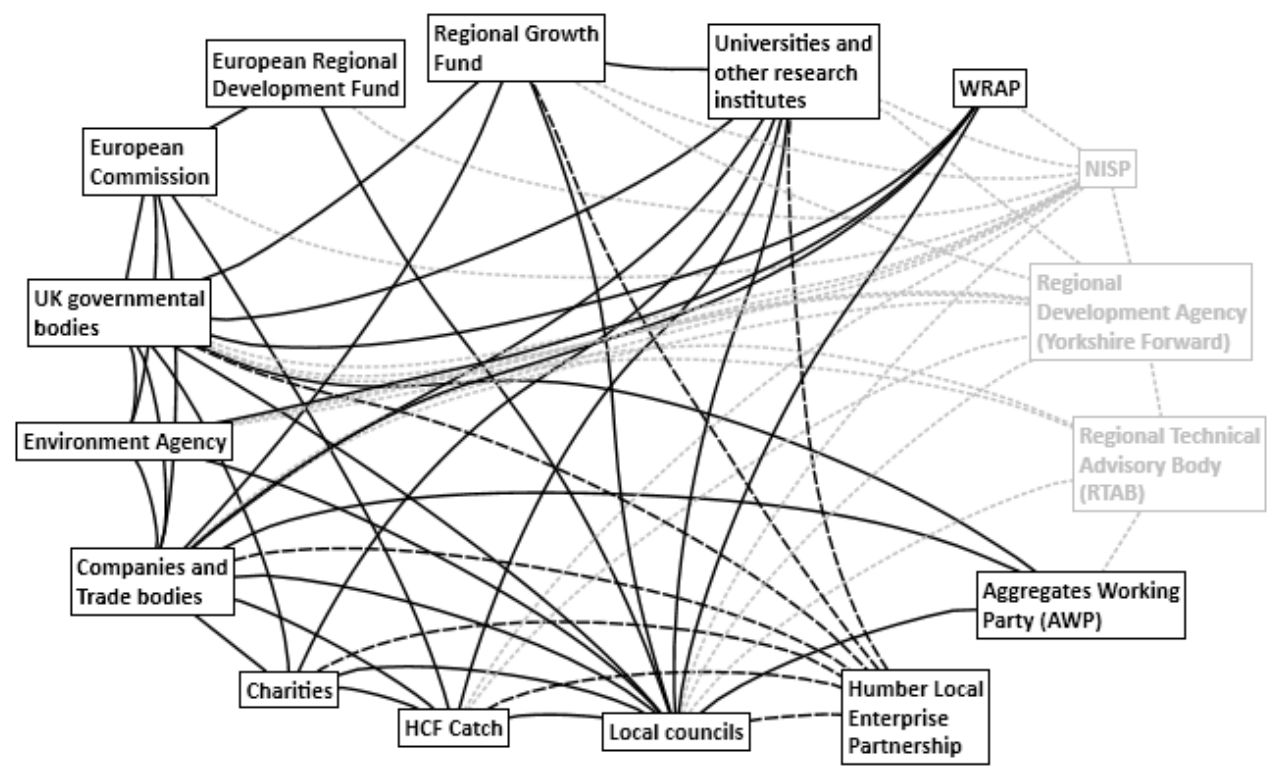

Roles of actors involved in the governance network

Interviewees identified a diverse range of roles when discussing economic development and innovation, under which they generally grouped bio-based developments and biowaste-to-resource innovation (Figure 3). The roles could be organised into regulatory and facilitative roles, which could have a more strategic or operational focus (Table 3). Aside from interviewees from NISP (and their regional delivery partner), EA, and WRAP who have worked on biowaste-to-resource innovation specifically, most interviewees could only play a general role in governing economic development and innovation as reflected in this quote:

Yes there probably are an awful lot of those synergies that should be happening, that maybe are (...), as a local authority it isn't something that we would 
necessarily get so involved with (...) because we're just not specialist enough to do that [initiating biowaste-to-resource innovation]. (Local council interviewee, 2014)

Since 2012 there were no dedicated governmental organisations, departments or publicly funded programmes for regional waste-resource planning, bio-based developments, or (bio)waste-to-resource innovation in the Humber region. That is not to say that organisations did not dedicate resources to these developments, such as reflected in the bottom-right quote in Table 3.

Figure 3: Governmental organisations perceived to have a broad diversity of roles to support economic development and innovation, within which they usually included biobased developments and biowaste-to-resource innovation. The roles could be organised into four categories (also see Table 3)

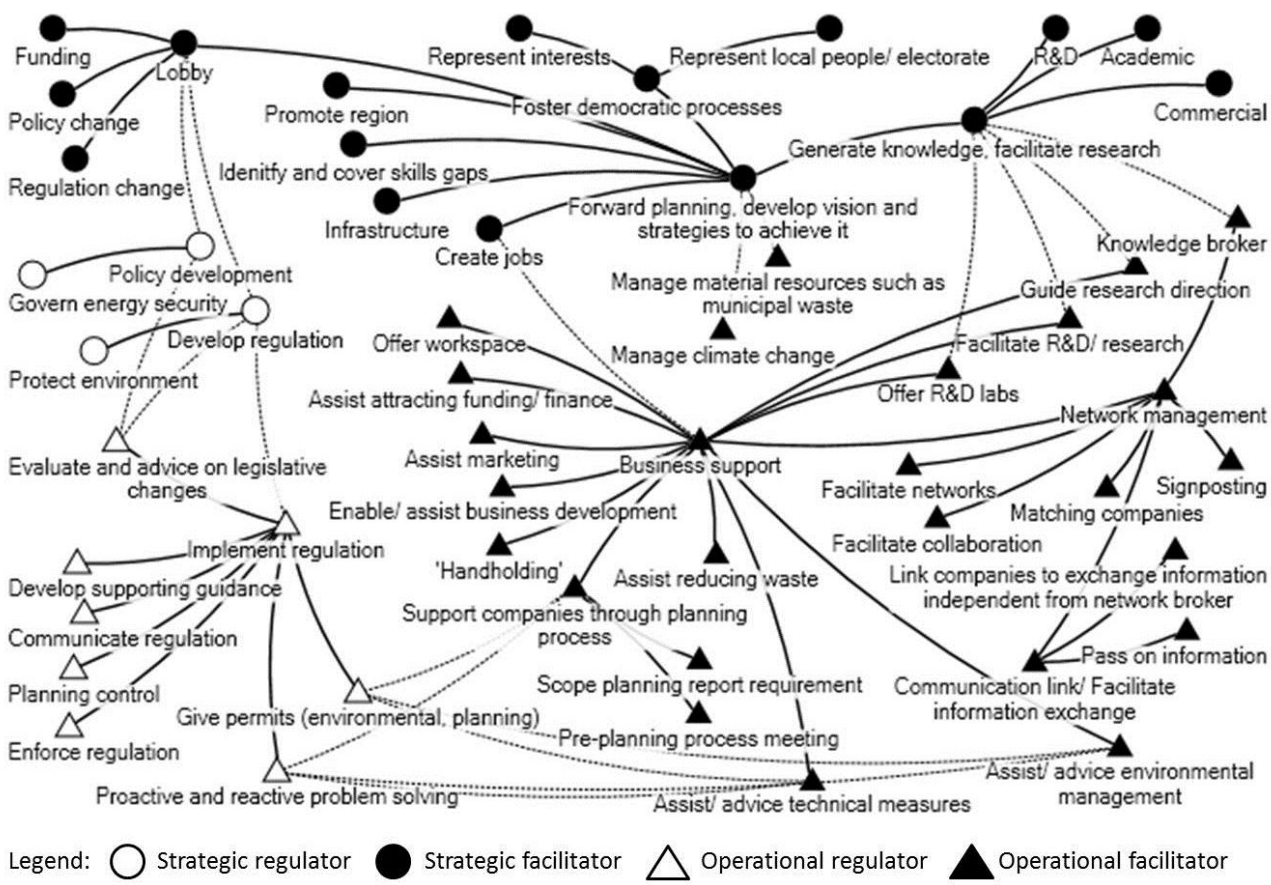


Table 3: Roles could be divided into regulatory and facilitative functions, and strategic and operational roles

\begin{tabular}{|c|c|c|}
\hline & Regulator & Facilitator \\
\hline 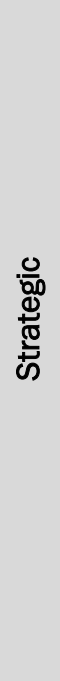 & $\begin{array}{l}\text { Provide long-term framework within } \\
\text { which economic development can take } \\
\text { place } \\
\text { “Now because of the way government } \\
\text { subsidised different renewable energy } \\
\text { schemes, the movement between kind of } \\
\text { different opportunities renewable energy } \\
\text { has shifted. And it is fair to say that the } \\
\text { government subsidies had a huge shift in } \\
\text { terms of what type of energy from waste or } \\
\text { renewable energy take place, and originally } \\
\text { there were high hopes for biomass type } \\
\text { developments and they haven't come to as } \\
\text { big a fruition as we thought, and instead } \\
\text { things like offshore wind have become the } \\
\text { very big players, and that's really because } \\
\text { government subsidy which has been key to } \\
\text { that." (Local council interviewee, 2014) }\end{array}$ & $\begin{array}{l}\text { Forward planning through democratic } \\
\text { processes, knowledge generation and } \\
\text { lobby activities } \\
\text { "It's making sure that the place is right, } \\
\text { so making sure that the infrastructure is } \\
\text { right, that we are creating the right } \\
\text { environment for business to either thrive, } \\
\text { that our local business grow, or invest in } \\
\text { the area from the outside. It's making sure } \\
\text { that people, workforce, is right." (Humber } \\
\text { LEP interviewee, 2014) }\end{array}$ \\
\hline 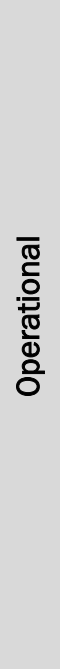 & $\begin{array}{l}\text { Deliver and evaluate regulation } \\
\text { “So we are a delivery body, which } \\
\text { means we don't set policy, and we don't if } \\
\text { you like set some of the initiatives that you } \\
\text { referred to like renewable energy ROCs and } \\
\text { things like that. Because we're a delivery } \\
\text { body and because we are specifically } \\
\text { tasked with delivery of certain regulations } \\
\text { that are given to us and a corporate } \\
\text { strategy that has been given to us, } \\
\text { protection of the environment, guardians of } \\
\text { the environment, that is our role. Now we } \\
\text { have checks and balances to ensure that } \\
\text { we are risk-based, that we are } \\
\text { proportionate and that we support not only } \\
\text { environmental protection but appropriate } \\
\text { sustainable development." (EA interviewee, } \\
\text { 2014) }\end{array}$ & $\begin{array}{c}\text { Deliver economic development } \\
\text { through business support and network } \\
\text { activities } \\
\text { "So things like [large-scale bio-based } \\
\text { development], for example, there was a } \\
\text { team member within the economic } \\
\text { development department of [local council], } \\
\text { almost exclusively working with [large-scale } \\
\text { bio-based development]. Because they } \\
\text { want that development, so there will be a } \\
\text { planning officer and an economic } \\
\text { development officer and potentially } \\
\text { somebody from employment working with } \\
\text { that company to help them through that } \\
\text { process to just get it in and to make it } \\
\text { happen." (Local council interviewee, 2014) }\end{array}$ \\
\hline
\end{tabular}

\section{Activities to deliver governance roles}

This section analyses how the governmental organisations, and associated organisations, carried out the roles that were identified in the previous section. The main activities put forward by the interviewees were the organisation of, and participation in, network activities; Sign-posting companies towards others involved in the governance within the region, and linked to that, communicating between companies and governmental organisations; Attracting funding into the region and cascading it through the governance system until it reaches e.g. companies; And finally the commissioning and carrying out of research (Table 4). A local council interviewee outlined the character of their activities: 
p. 157. Analysing the governance system for the promotion of industrial symbiosis in the Humber region, UK

So our role is very much hand holding, making connections, networking, supporting through planning processes, through the project process, through recruitment of the workforce, it's signposting as well... (Local council interviewee, 2014)

It is notable that for almost all activities, interviewees reported that capacity had reduced since 2012 (Table 4).

Comparing the roles (i.e. what governmental and associated organisations perceived they should be doing) to the activities (i.e. what they were actually doing) revealed mismatches which presented themselves in a variety of forms. Most interviewees talked about innovation in terms of having a role in research, R\&D and business development. However, it was much harder for them to explain how innovation was actually promoted through their activities. Similarly, while various local strategies discuss the promotion of innovation, interviewees questioned whether enough operational capacity was available within the governance system to implement such strategic aims (further detailed in the next section). For example, in some councils R\&D facilities have been prepared for companies, as captured in Table 4 under 'Provide research facilities', but these facilities have never been used for R\&D purposes to the best of the interviewees' knowledge:

...that [R\&D spaces] was developed in the days of the Regional Development Agencies which in our case was Yorkshire Forward, and prior to Yorkshire Forward being dissolved along with all the other RDAs, there should have been two funding streams. One was the capital funding stream which basically got the building built, which happened but there should also have been a revenue funding stream which was there to develop the higher end [i.e. higher-end uses for by-products] and that never happened. (Local council interviewee, 2014)

While a mismatch was perceived between roles and activities for innovation specifically, the mismatch between roles and capacity to deliver on technical, environmental and resource management advice was even more visible (see e.g. 'Regulatory advice' in Table 4). These roles were partly carried out by NISP, whose public funding was stopped. Moreover, funding cuts also reduced capacity within the local councils and the EA (further discussed in the next section) to deliver on environmental planning, protection and management which also affects the ability to support biowaste-to-resource innovation, as expressed in the following quote:

Ten years ago (...) the Environment Agency had all the expertise it needed to support industrial symbiosis and development. In terms of technical expertise, people who had experience of all the industry sectors which had potential opportunities. (...) Unfortunately now, ten years later, particularly right now this year, I don't feel it has either the technical expertise, or even the number of people now that it would need to support industrial symbiosis. (EA interviewee, 2014)

A different kind of mismatch could be identified in the EA's roles and activities. While the organisation's core role is to prevent pollution and harm to the environment and human health, part of the activities (such as during permit applications/exemption procedures) is the assessment of economic benefits, which seems to go beyond their role as it does not contribute to assessing environmental effects of industrial activities. 
Table 4: Activities carried out by governmental organisations and associated organisations. Legend: Black means activity carried out by the organisation, Dark grey is activity carried out by fewer people/departments in that organisation since 2012, and Light grey is activity not carried out anymore by that organisation since 2012 in the Humber region. In the bottom row, downward arrow indicates reduced capacity, and 0 means capacity remained similar.

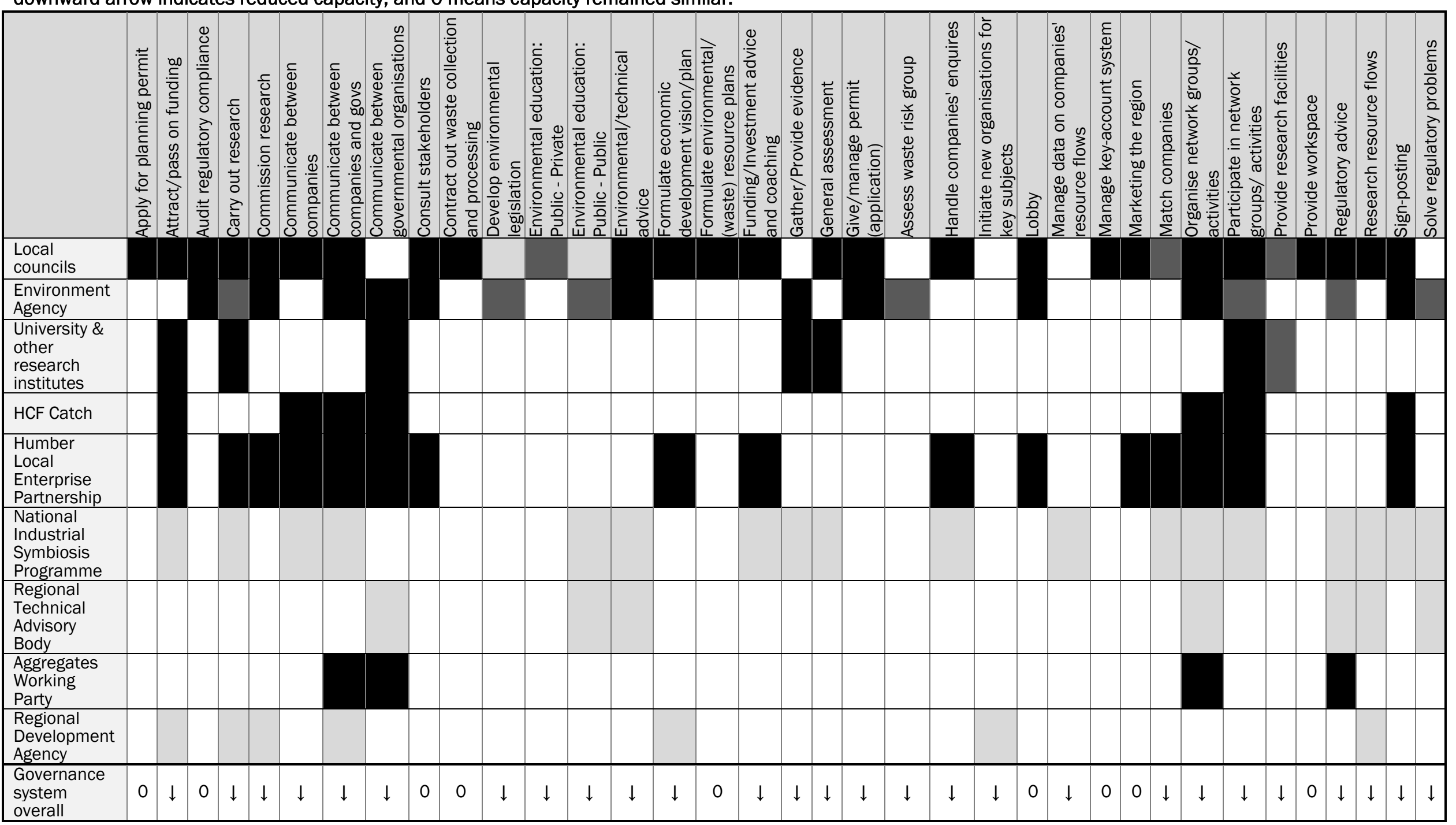


An important mismatch was observed between generalist governance activities and the specialist activities required to support biowaste-to-resource innovation. Network activities were an important part of delivering governance within the Humber region. General open networking activities could be distinguished from subject-specific forums. This nurtured the idea that perhaps two broad types of governance processes and associated networking activities could be distinguished: General governance activities to maintain basic processes, such as infrastructure maintenance and general education, and activities to govern specific changes, such as structural regional economic development including the emergence of new sectors and/or the (re)development of industrial areas. This idea needs further thought, but there were indeed various projects and programmes within the Humber region to deliver specific changes, such as the Green Port Growth Programme which is focused on supporting businesses to capitalise on large-scale developments particularly in the offshore wind industry. Business support activities, such as presented in Table 4, are offered through this programme. Although the motivation to provide bespoke and even specialist support was observed in the organisations involved (local councils, Humber LEP and universities), it was difficult to achieve with the funding available within the programme. Funding enabled generalist activities which led to identifying the need for specialist support, such as for research and training, but additional funding application was often necessary to deliver it, as described in the following quotes outlining the generalist and specialist support:

With the Green Port Growth programme we have a number of partners. The business support strand should really be the first interaction. And what the business support will do, it will go into a company and do an audit of that company to see where it is now, where it needs to be, where it wants to get to, where its opportunities are. And then from the initial audit it will then maybe draw specialist consultancy (...) It may well have a technology that needs to develop, so the University of Hull lead on that programme (...) We're generalist, we don't specialise in, go in with one particular thing. (Local council interviewee, 2014)

It might be that they just need a couple of days specific consultancy from an academic or an R\&D professional and it might be the University of Hull that can provide that, or it might be that they need a bit of proof of concept work doing and we can help them with that or it might be that it's obvious that they need a bigger piece of funding that the R\&D director and his pot of money will be used to help develop that even bigger research bid. (University of Hull interviewee, 2014)

The predominantly generalist approach, and the associated funding allocation, seems to be inconsistent with the delivery of specialist activities required for specific projects and programmes. However, operationalising and delivering specific targets requires resources such as money, people and knowledge, which were not always present within, or could not be acquired by, the organisations involved (further explained in the next section).

Summarising the comparison of perceived roles and actual activities, there seem to be issues with delivering sufficiently specific innovation support, environment, and waste and resource management at the regional level, all of which are directly relevant to biowaste-to-resource innovation. 


\section{Competencies in governance network}

Competencies within governmental organisations were perceived by companies as important in overcoming or strengthening legislative barriers (Velenturf, 2015). Additionally, the preceding results indicate that there have been some dynamics in the competencies. Hence this section further analyses the three components of competencies, attitude, knowledge, and skills, within governmental and associated organisations and implications for biowaste-to-resource innovation.

\section{Attitude}

When discussing attitude, the importance of flexibility was brought up almost unanimously by the interviewees. While interviewees perceived some departments of governmental organisations as more flexible, which was also associated with openness, being proactive, collaborative and entrepreneurial, others were considered inflexible, which was associated with working in a highly structured, rigorous, precautionary and sometimes overly bureaucratic manner. Flexibility varied because of 1) role and focus, 2) policy and regulation, 3) knowledge and skills, 4) people and money, and 5) timing of interactions.

Role and focus: The degree of flexibility that a department could provide was associated with their role. For example, regulatory departments were generally perceived to have less flexibility than economic development departments. This was also related to the focus of a department which was partly determined by the policy and regulation being developed and/or implemented (compare for instance quotes about regulators and facilitators in Table 3).

Policy and regulation: Different actors have varying degrees of power and responsibility to develop and/or implement policy and regulation. Furthermore, despite what might seem intuitively right, the amount of policy and regulation did not appear to be directly related to the flexibility that a department could provide. For example, it was suggested that the EA had to implement much new waste regulation since 2007 which arguably made them less flexible in their interaction with companies. Conversely, the councils' planning departments saw regulation for waste developments being withdrawn (Government, 2014), and perhaps this decreased amount of regulation should have sped up planning applications, but in reality it incapacitated them to make decisions as expressed in the following quote:

All of those [planning policy statements] went and they were replaced by something called the NPPF, the National Planning Policy Framework and that covers everything, it covers residential, it covers environment, it covers minerals, it covers every aspect of planning, but it doesn't cover waste, because waste is intended to have its own separate national policy but we're still waiting for that, so we're just in a policy vacuum really. (Local council interviewee, 2014)

Knowledge: Simultaneously, planning departments also increasingly experienced knowledge gaps necessary to satisfy their regulatory obligations during planning applications. Interviewees in other departments and organisations also observed how knowledge gaps appeared in recent years (further discussed below in "Knowledge and skills"). Generally, knowledge of policy and regulation as well as markets and industrial processes supported a more flexible attitude towards potential economic developments, although knowledge requirements did vary between departments. Acquiring and processing knowledge requires the right amount of people with the right competencies. However, particularly the EA (see quote on p16) and local councils have 
lost knowledge capacity because restructuring and austerity measures led to redundancies in these organisations (also see EA, 2015a; LGA, 2014; NAO, 2014).

People and money: The number of redundancies, particularly visible in EA and councils' environmental departments, coincided with the stop in public funding for a) NISP and $b$ ) the network meetings for local council planning officers working on waste (Regional Technical Advisory Board in Figure 2). It appears that environment and waste have been downgraded as a priority at national government level, and as a result lower government levels have reduced resources to work in a proactive and flexible manner with companies on (bio)waste-to-resource innovations. However, with circular economy and resource scarcity rising on the political agenda, interviewees suggested that these measures should be reviewed as there is a need to improve governance of waste and resource management such as suggested by this interviewee from the EA:

What the Environment Agency needs to do is train its staff to be regulators. By that I don't mean people who just go out and visit sites and inspect sites and stop everything, that's not what I mean by being a regulator. I mean to be able to go onto a site and say to a site operator, what you're doing is causing a problem, let's work together to solve that problem. (...) So what we need to do is have in place people who can hold those conversations and work in that collaborative way, cause we solve our environmental problem, they solve their waste disposal or financial problem. (EA interviewee, 2014)

Timing: Timing was important in relation to flexibility, because regulators could be more flexible and open before permit application processes start. During permit applications they need to follow procedures and have less flexibility to advice applicants. Conversely, as one local council interviewee explained, before the application process there is more space to collaborate and provide guidance to increase chances for a successful permit application:

(...) definitely best beforehand when they're still in that development stage where (...) they're still kind of at the drawing board almost. (...) whereas obviously once it's at planning application stage it's either take it or leave it but there isn't much chance to kind of redesign it. So from my point of view that's best to do it up-front. (Local council interviewee, 2014)

However, regulators often perceived to be engaged too late and as a result they could not be as flexible as they might want to be. As a result companies and other departments, such as economic development, perceived the regulators as too inflexible and engaged them even later in subsequent developments which worsened the interaction. This suggests that breaking this spiral could benefit proposed economic developments. At the moment, however, interviewees suggested that government employees do not have any performance indicators for collaboration. In other words, no performance boxes are ticked by spending time and resources collaborating within and between governments. Instead, whether or not collaboration takes place comes down to the individual employee.

\section{Knowledge and skills}

The previous section indicated that knowledge availability could impact on attitudes within governmental and associated organisations. This section will first outline knowledge and skills gaps regarding bio-based developments involving biowastes, and then analyse knowledge and skills that were available within the governance network. 
The results will suggest that some issues with knowledge and skills could perhaps be resolved by 'rewiring' the regional governance network.

The interviewees identified a broad range of knowledge gaps regarding bio-based developments (Table 5). The gaps can be grouped into questions regarding social and metabolic networks. Understanding social network developments pertains to knowledge about promoting innovation, particularly through collaboration between governmental organisations across all governance levels and also within the Humber region through public-private interactions. Understanding metabolic networks pertains to knowledge about existing and future resource flows, such as expressed in the following quotes respectively:

We have some technical knowledge gaps. One of the difficulties is, we have to make these risk-based decisions and the more uncertainty we have, the more tendency there is to have the precautionary approach. And the precautionary approach is an area where conflict can exist with industry because they want to be more risk-taking and they perceive us to be risk-averse (...) So some complex wastes, it's quite difficult to be confident that we've identified all the hazards and then as a result managed appropriate risks from that hazards. So we are at the moment doing some research work trying to improve that knowledge gap, but that is one aspect where we speak to industry and we say, you need to better characterise your waste, then we can reduce our uncertainty and as a consequence we will be less risk averse. (EA interviewee, 2014)

What I think is missing is a, almost a strategic plan or overview of what is happening in the whole of the waste sector (...) with a view to actually, I guess plan into the future in terms of what those waste streams are going to be and what facilities are going to be available. (Local council interview, 2014)

Analysing the knowledge gaps regarding metabolic networks, the demand for knowledge on quantity and quality of resources was directly present in council departments such as inward investment (for example: is a development using a certain resource flow viable?) and planning (for example: is it safe?). This demand could not be satisfied at all times. Councils could only meet these knowledge needs if they had the network and budget to acquire knowledge via a specialist consultancy, but this was not within range of all local councils. Councils previously obtained information on resource and waste flows via, amongst other routes, the RDA and NISP, but these disappeared from the regional governance system in 2012.

Having observed significant knowledge and skills gaps, the results also suggested that these knowledge and skills were partly present within the regional governance network already (Table 5). For example, interviewees generally were well-aware of the bio-based developments in their (local) area. Some interviewees also had good knowledge of technologies and resources which supported their varying governance activities, particularly when combined with understanding the associated market and/or regulatory environment and collaboration skills to overcome challenges. However, the data on knowledge and skills present in the governance network was much thinner and more scattered over various subjects and organisations when compared to the fairly coherent knowledge gaps. Nevertheless, a comparison of the missing and present knowledge and skills suggests that a part of the problem could be solved by 'rewiring' the governance network, i.e. connecting people who do have the knowledge and skills with people who also need them. 
Table 5: Comparison of missing and present knowledge and skills within the regional and local governance network

\begin{tabular}{|c|c|c|}
\hline & $\begin{array}{l}\text { Metabolic networks: Understanding } \\
\text { current and future resource flows. }\end{array}$ & $\begin{array}{l}\text { Social networks: Understanding innovation } \\
\text { and collaboration across governance } \\
\text { levels and within the region. }\end{array}$ \\
\hline 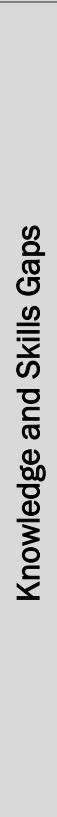 & $\begin{array}{l}\text { What are the resource characteristics } \\
\text { exactly? } \\
\text { What are the environmental benefits } \\
\text { and potential risks? } \\
\text { Which resource flows are present? } \\
\text { Which bio-based developments are } \\
\text { realised? } \\
\text { Who produces what? Who uses what? } \\
\text { What does the whole resource network } \\
\text { look like? } \\
\text { How could resource flows 'fit together' } \\
\text { better? } \\
\text { What are the future economic } \\
\text { challenges and opportunities? } \\
\text { Which industries could be attracted into } \\
\text { the region and how could they fit in the } \\
\text { resource network? }\end{array}$ & $\begin{array}{l}\text { How do people innovate? } \\
\text { How can innovation be planned for? } \\
\text { How are people collaborating now for (bio- } \\
\text { based) innovation? } \\
\text { What role do individual people/organisations } \\
\text { play in innovation? } \\
\text { How much capacity, (people and their skills } \\
\text { and knowledge) is needed to support bio- } \\
\text { based innovation? } \\
\text { How much money and time is needed? } \\
\text { What is industrial symbiosis/(bio)waste-to- } \\
\text { resource innovation and how can it help } \\
\text { achieving policy/regulatory and economic } \\
\text { targets? } \\
\text { How can strategic and operational } \\
\text { governance levels be linked: } \\
\text { How can bio-based plans be implemented? } \\
\text { How can 'technical' knowledge about } \\
\text { innovation processes and bio-based } \\
\text { developments be accessed/made known to } \\
\text { strategic governance levels? }\end{array}$ \\
\hline 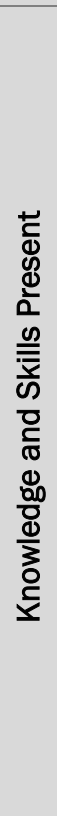 & $\begin{array}{l}\text { Awareness of bio-based developments } \\
\text { in the region. } \\
\text { Knowing what industries look like now. } \\
\text { Network knowledge of industrial } \\
\text { symbiosis/ bio-based collaborations. } \\
\text { Technical knowledge of bio-based } \\
\text { developments. } \\
\text { Resource knowledge enabling the } \\
\text { regulating of developments. }\end{array}$ & $\begin{array}{l}\text { Abstract strategic understanding of bio- } \\
\text { based/waste-to-resource developments. } \\
\text { Understanding how to collaborate, innovate, } \\
\text { network, and/or learn. } \\
\text { Knowing how to innovate and where } \\
\text { knowledge and money could be sourced. } \\
\text { General understanding of business support. } \\
\text { Understanding how regulators and business } \\
\text { could collaborate. } \\
\text { Planning control knowledge about bio-based } \\
\text { developments. } \\
\text { Insider understanding of bio- } \\
\text { based/industrial symbiosis developments. * } \\
\text { Experienced-based advanced collaboration } \\
\text { skills regarding waste-to-resource and bio- } \\
\text { based activities. } \\
\text { Understanding how the waste market works. } \\
\text { Understanding the strategic, technical and } \\
\text { commercial challenges and knowledge } \\
\text { requirements to bring developments into } \\
\text { practice. }\end{array}$ \\
\hline
\end{tabular}

* Skilled networkers have left/are leaving councils, EA and NISP; When RDA and NISP disappeared from the regional network, not all critical skills were maintained or transferred to other organisations. 
Table 5 demonstrates the need to generate new knowledge through research activities. Interviewees distinguished academic, regional, commercial and R\&D knowledge. It was suggested that different actors were better positioned to deliver these knowledge types. However, in general, interviewees perceived that universities are expected to deliver on all these knowledge types, while universities might actually be neither best positioned nor have an interest in participating in all research activities. For example, commercial knowledge was observed to be developed by companies during their trading activities and this did not require a research institute at any time. In other words, it was suggested that the generation of various knowledge types, and the organisations that need to be involved, requires rethinking at a strategic and operational level. This observation is linked to the knowledge gap about effectively linking strategic and operational levels in the governance network (Table 5), which is linked to the discussed network changes (Figure 2). Having discussed roles, activities and competencies, the next section will expand on the effects of the network dynamics on the functioning of the whole regional governance network which also affected biowaste-to-resource innovation.

\section{Effects of network changes on governance for the biowaste-to-resource innovation}

Elaborating the knowledge gap regarding ways to effectively link EU/national and regional/local governance levels (Table 5), there are various high-level legislative drivers to promote economic development, carbon reduction, waste reduction and resource circulation, but these ambitions seem disconnected from an understanding of regional/local level governance responsible for the implementation of (parts of) these ambitions. The interviewees did indeed indicate that councils do have strategies covering subjects relevant for biowaste-to-resource innovation, such as sustainable development, climate change, resource efficiency, natural resources, and innovation. However, there is insufficient capacity in terms of staffing, money and competencies to operationalise these strategies, educate the staff involved and ultimately to deliver the strategies. Similarly, Eadson (2008) observed that the responsibility for the climate change mitigation strategy was devolved to local authorities, while the power to achieve carbon reduction targets remained with the national government. He continued to argue that the potential to achieve such targets needs to be present at each governance level. Before 2012, the RDA played an important role in connecting the higher and lower governance levels through the creation and exchange of knowledge, since then the Humber LEP could only partly take over this function.

The dissolving of the RDA and creation of the Humber LEP had positive and negative consequences for the regional governance network. The main advantage of the Humber LEP is that they are based in the region and perceived to be much more involved in the development of the Humber region when compared to the RDA, which was perceived to be based too far away (in Leeds) and to prioritise economic development in other parts of Yorkshire and the Humber. Conversely, the dedicated Humber LEP has promoted more joined-up thinking and aligning of visions and objectives within the region as expressed in the following quote:

Internal politics can be detrimental for the Humber region. I do think it's improved under the LEP (...) I think there is still work to be done around the different councils, the different councils and the LEP. I think there still needs to be more of this unification, more a single voice from the Humber, so everybody on the Humber working together, that can only be better for industry. (University of Hull interviewee, 2014) 
However, being an organisation almost completely consisting of public and private partners active in the Humber region at this moment in time, they are also constrained by their own perspectives. The organisations involved in the Humber LEP are experts on what they are doing in the region now, not on what might happen in the Humber region in the longer term. In contrast, the RDA was better placed to develop a more global and longer term perspective on regional development relatively independent from current public and private actors, and as such it was in a position to identify potentially important future structural economic changes that were not necessarily in the interest of private partners active in the region already. One interviewee detailed how the RDA could bring new technologies to market:

Well I think that you had experts [in RDA] in kind of energy field, chemicals field, who were not tied to a single company, who kind of had one thought in a research type camp, so they understood new technologies coming along but then had public funding and money to try then to collaborate with industry, trying to bring some of that stuff to fruition. (Local council interviewee, 2014)

This operational capacity tied into more 'independent' strategic planning capacity has now largely disappeared from the regional governance system and this could impact on the long-term economic resilience of the region.

Besides the changes associated with the dissolution of the RDA, interviewees suggested that the local councils and EA also had experienced important changes in the operational capacity to support (biowaste-to-resource) innovations. The EA had to make a large proportion of officers redundant (also see EA, 2015a). Consequently interviewees indicated that they had to focus on their core task, which is regulating, leaving less space to deliver other tasks such as engagement and providing guidance. This was considered to be an issue particularly for the emerging and growing biowaste sector (also see EA, 2015b), which has seen many start-ups and an influx of new companies as well as continuously emerging innovations and new challenges:

I mean the waste sector is a developing sector, it's becoming more technically difficult in the waste sector with increasing waste-to-energy plants. But if you look at traditional waste sector, which is skips and general waste disposal or landfill sites, it doesn't tend... it is regulated a lot stricter because the law itself, for waste, is a lot more prescriptive, it is a lot more black and white, you will do this or you will do that. Whereas for chemical sites, you will do this somehow, it's left more open to the actual individual site to determine what they should be doing. (EA interviewee, 2014)

Moreover, NISP previously played a key role in solving regulatory problems, particularly regarding innovative resource flows, in collaboration with the EA. The EA anticipated issues arising from the resource innovations facilitated by NISP:

We thought there could be all sorts of issues that would come our way anyway as the environmental regulator and that it would be better to be handle it early in the discussion rather than having to fire fight when problems came along. (EA interviewee, 2014)

However, that collaboration to solve regulatory issues ended when public funding for NISP was stopped.

The EA also faces increasing challenges because of biowaste developments coming forward, which tend to require involvement of various teams. Interviewees indicated 
that these developments tend to involve a wide range of diverse activities which tend to be regulated by different teams. In some cases also referrals outside the EA were required. Hence these integral developments within a largely sectoral governance system present both networking and regulatory challenges for the EA and the companies involved.

Concluding this section, it is clear that rather than reducing network connectivity and capacity within and between governmental and associated organisations, there is a need to increase capacity within the whole network and enable better network connectivity through the provision of required resources in order to promote biowasteto-resource innovation.

\section{Discussion and recommendations}

Summarising the results, since 2012 organisations such as NISP, the Regional Technical Advisory Board for waste planners, and the RDA lost public funding and/or were dissolved whilst simultaneously the EA and local councils faced severe funding cuts. As a result, capacity to deliver the majority of governance activities decreased, which included activities that are of key importance to biowaste-to-resource innovation such as researching and producing and managing data on resource flows. Indeed, knowledge gaps regarding these activities and other subjects were identified. Knowledge gaps were linked to less flexible attitudes which were also reflected in the reduced capacity to solve regulatory problems. The introduction of the Humber LEP into the governance network did improve connections between the actors around the Humber estuary which promoted more joined-up thinking for economic development. This increasing connectivity within the governance network could contribute to channel knowledge and skills from places in the network where it is present to places where it was perceived to be missing. However, aside from economic development, the Humber LEP seems to have less capacity than the RDA to support implementation of government policy and regulation on for instance innovation for carbon reductions and increased resource efficiency in collaboration with the local councils and the existing business community. As such, the linkages between EU/national and regional/local level governance have weakened on subjects that are important for the promotion of biowaste-to-resource innovation. Finally, it should be concluded that formal governance to specifically monitor, plan and promote biowaste-to-resource innovations or other biobased developments is almost completely absent in the Humber region.

\section{Network governance and biowaste-to-resource innovation}

This research was an attempt to gain an understanding of a complete regional governance system for industrial symbiosis from the perspective of the governmental organisations that were involved. It documented practical insights in the form of perceived roles and activities while registering the challenges summarised above. The adverse effects associated with decreasing capacity within the network gives some weight to the envisioned importance of network governance (Lundvall et al., 2002; Chaminade and Edquist, 2005; Tödtling and Trippl, 2005; Alkemade et al., 2011; Bergh et al., 2011). Furthermore, it explained some of the variations in government attitudes when engaging in industrial symbiosis, which either help overcome or, alternatively, strengthen barriers when companies implement resource synergies (Salmi et al., 2012; Velenturf, 2015). Consequently it can be concluded that this research has made original contributions to industrial symbiosis literature. 
The contributions are, however, inductive in nature and require further research to consolidate the findings. Transferability of this research needs to be studied because, although all English regions were affected by similar changes in the organisational composition of the networks, the austerity measures for the EA and local councils may have been received and dealt with differently in other areas of the country. For example, Wells et al. (2011) argued that the relatively deprived councils in the Yorkshire and Humber region were particularly vulnerable to public spending cuts as they had fewer reserves to buffer the effects of austerity measures on a wide range of services. Furthermore, a more comprehensive comparison of the role of network governance and other forms of governance (see e.g. Bulkeley et al., 2007) within England would be valuable in understanding how resource innovation and particularly industrial symbiosis can be governed most effectively. Additionally, it would also be valuable to repeat such comparison in countries where models of promoting industrial symbiosis, ranging from self-organised to fully planned, have had varying success (Shi et al., 2012). Finally, the more practical question pertaining to improving the existing governance system for industrial symbiosis deserves further attention (discussed in the next section).

\section{Recommendations for the governance of biowaste-to-resource innovation}

This research has analysed how capacity within the governance network in the Humber region has decreased since 2012 and explored the ways in which this was perceived as problematic. Therefore this final section turns to the question: how can the governance network for biowaste-to-resource innovation be strengthened?

Within a context of decaying politics acting upon climate change and environmental protection (While, 2013), the results showed decreasing governance capacity within the regional network. Nevertheless, biowaste-to-resource innovation (as part of a growing movement towards the circular and bioeconomy) has been gaining momentum at the EU and, arguably, national levels of government (DEFRA and BIS, 2012; Science and Technology Select Committee, 2014; Government, 2014, 2015a; EC, 2015; Velenturf, et al. Forthcoming). Plans to promote the bioeconomy focusing on waste, i.e. biowaste-to-resource innovation, are still at an early stage. An initial strategy has been outlined and potential governance measures have been analysed and recommended to national government (Government, 2015a; Allen et al., 2015). The government's strategy largely focuses on promoting collaboration between industry and academia whilst the strategy itself is a collaborative result from various governmental departments (including DEFRA, BIS, DECC, DFT and DCLG). It is certainly encouraging to see actions being taken to build the innovation 'ecosystem' for the bioeconomy as well as the governmental collaborations which could lead to more integration of the relevant areas of policy and regulation. However, the current plans do not recognise the limited capacity within the regional governance system to engage in the proposed collaborations and to operationalise national government strategies and plans. In fact, the crucial role of the regional governance system in terms of planning and environmental permits and attracting inward investment, for instance for the envisioned innovations, does not seem to be recognised at all. Hence it would be worthwhile for the national level governmental departments to engage more directly with the actors in the regional governance network to gain a more realistic understanding of present capacity. To increase regional capacity, the results of this research suggest that the UK government needs to work with the regional governance actors to dedicate the resources for attracting expert knowledge on both technical and social aspects of biowaste-to-resource innovation and also for training regional governance officers in emerging technologies. 
Increasing regional capacity is essential in the uptake of biowaste-to-resource innovations. A range of policies and regulations come together at the regional level when a company initiates a biowaste-to-resource innovation - consider for example the Renewables Obligation, Landfill Tax, Environmental Permitting regulations, and the National Planning Policy for waste (introduced shortly after interviews for this study were completed, see DCLG, 2014). These policies and regulations are not necessarily aligned with each other, Rotherham (2010: 35) reports an 'almost total absence of a genuine joined-up vision for the future', or with the innovation at hand. Therefore regulatory constraints need to be solved (Material Security Working Group, 2015; Allen et al., 2015; Velenturf, 2015). This requires flexibility from governmental organisations which, as pointed out in this study, depends in part on the knowledge and skills of the officers involved. ${ }^{2}$ Moreover, it may require collaboration within and between governmental organisations in the Humber region as well as the associated departments at the national level (for instance, local councils and DCLG; Environment Agency and DEFRA), particularly when regulatory changes need to be carried through in an efficient manner (similar to suggestion by Zhu et al., 2014). A new regional working group/coordinator to solve regulatory problems and, when necessary, communicate with the national level departments could be useful to streamline the processes and concentrate expertise on this subject ${ }^{3}$ (such as York North Yorkshire and East Riding LEP, 2015). Interviewees suggested that this task used to be carried out by the RDA and NISP but the connections and expertise dispersed or completely disappeared in 2012. The suggested working group or coordinator could also contribute to the implementation of national level strategies and plans for the bioeconomy (also see Allen et al., 2015).

In sum, it could be suggested that the governance for biowaste-to-resource innovation in the Humber region needs strengthening by a) increasing integration and flexibility of the regulatory 'landscape' across governmental departments; b) building better connections between national and regional level governmental organisations as well as within the Humber region; and c) investing in knowledge and skills as well as operational capacity of regional governance actors. These recommendations should contribute to restoring the balance between regional capacity and the national ambitions to promote biowaste-to-resource innovation.

\section{Notes}

1 In this study the bio-based economy was interpreted as the usage of biomass for materials, chemicals, fuels and power, and the bioeconomy also includes the use of biomass for food and feed.

2 Knowledge and skills gaps of regional governance actors were unfortunately overlooked in the "Skills for a green economy" report (Government, 2011).

3 Interviewees recommended a 'NISP 2.0' (see, (Laybourn and Morrissey, 2009). 


\section{Acknowledgements}

I would like to thank all research participants for their time, openness and insights. I am also grateful for the data shared by Alexandra Penn and Frank Schiller, the support of Kate Burningham throughout this study, and the thoughtful engagement of the anonymous reviewers and editor. Finally, this study was part of my doctoral research at the University of Surrey, Centre for Environmental Strategy, and partially supported by the UK Engineering and Physical Sciences Research Council for programme grant $\mathrm{EP} / \mathrm{H021779/1} \mathrm{(Evolution} \mathrm{and} \mathrm{Resilience} \mathrm{of} \mathrm{Industrial} \mathrm{Ecosystems).}$

*Correspondence address: Anne Velenturf, Centre for Environmental Strategy (D3), University of Surrey, Guildford, GU2 7XH. Email: a.velenturf@surrey.ac.uk

\section{References}

Alkemade, F., Hekkert, M.P. and Negro, S. O. (2011) Transition policy and innovation policy: Friends or foes? Environmental Innovation and Societal Transitions, 1, 125-129.

Allen, B., Nanni, S., Schweitzer, J.-P., Baldock, D., Watkins, E., Withana, S. and Bowyer, C. (2015) International review of Bio-economy Strategies with a Focus on Waste Resources. London: Business, Innovation and Skills.

Asheim, B.T. and Isaksen, A. (2002) Regional innovation systems: the integration of local 'sticky'and global 'ubiquitous' knowledge. The Journal of Technology Transfer, 27, 1, 77-86.

BIS (2011) UK Innovation Survey 2011. London: Business, Innovation and Skills

Bondholders (2014) New energy: The Humber is vital energy provider. Hull: Bondholders.

Borgatti, S. P., Mehra, A., Brass, D. J. and Labianca, G. (2009) Network analysis in the social sciences. Science, 323, 5916, 892-895.

Broekel, T., Buerger, M. and Brenner, T. (2010) An investigation of the relation between cooperation and the innovative success of German regions. Papers in Evolutionary Economic Geography, 10, 1, 52-78.

Bryman, A. (2012) Social research methods, fourth edition. Oxford: Oxford University Press.

Bulkeley, H., Watson, M. and Hudson, R. (2007) Modes of governing municipal waste. Environment and Planning A, 39, 11, 2733-2753.

Chaminade, C. and Edquist, C. (2005) From theory to practice: the use of systems of innovation approach in innovation policy. Paper no. 2005/02. Lund: Lund University.

Chertow, M.R. (2000) Industrial Symbiosis: Literature and Taxonomy. Annual Review of Energy and the Environment, 25, 1, 313-337.

Christensen, J. (2012) The Kalundborg Symbiosis: What, who, when, how and why? Presentation at Centre for Environmental Strategy seminar, 28 March, Guildford, UK.

Costa, I. and Ferrão, P.C. (2010) A case study of industrial symbiosis development using a middle-out approach. Journal of Cleaner Production, 18, 10, 984-992.

DCLG (2014) National Planning Policy for Waste. London: Department for Communities and Local Government.

DEFRA and BIS (2012) Resource Security Action Plan: Making the most of valuable materials. London: Department for Environment, Food and Rural Affairs.

Desrochers, P. (2004) Industrial symbiosis: the case for market coordination. Journal of Cleaner Production, 12, 8-10, 1099-1110. 
Deutz, P. and Frostick, L.E. (2009) Reconciling policy, practice, and theorisations of waste management. Geographical Journal, 175, 4, 247-250.

Deutz, P. and Loppolo, G. (2015) From Theory to Practice: Enhancing the Potential Policy Impact of Industrial Ecology. Sustainability, 7, 2, 2259-2273.

Dobbs, R., Oppenheim, J., Thompson, F., Brinkman, M. and Zornes, M. (2011) Resource revolution: Meeting the world's energy, materials, food, and water needs. McKinsey Quarterly and Company.

EA (2015a) Annual Report and Accounts for the year 2014 to 2015. Rotherham: Environment Agency.

EA (2015b) Regulating the waste industry: 2014 evidence summary. Rotherham: Environment Agency.

Eadson, W. (2008) Climate change mitigation in Local Area Agreements: an enforced lack of ambition? People, Place and Policy Online, 2, 3, 140-150.

EC (2015) Closing the loop - An EU action plan for the Circular Economy. Brussels: European Commission.

EC (2011a) Roadmap to a Resource Efficient Europe. Brussels: European Commission.

EC (2011b) A resource-efficient Europe - Flagship initiative under the Europe 2020 Strategy. Brussels: European Commission.

Ehrenfeld, J. and Gertler, N. (1997) Industrial ecology in practice: the evolution of interdependence at Kalundborg. Journal of Industrial Ecology, 1, 1, 67-79.

EU (2012) Regional Innovation Scoreboard 2012. Enterprise and Industry Magazine.

Finster, M.P. and Hernke. M.T. (2014) Benefits Organizations Pursue when Seeking Competitive Advantage by Improving Environmental Performance. Journal of Industrial Ecology, Special feature on industrial ecoloy as a source of competitive advantage, 18, 5, 652-662.

Flanagan, K., Uyarra, E. and Laranja, M. (2011) Reconceptualising the 'policy mix' for innovation. Research Policy, 40, 5, 702-713.

Flanagan, K., Uyarra, E. and Laranja, M. (2010) The 'policy mix' for innovation: Rethinking innovation policy in a multi-level, multi-actor context. Manchester Business School Working Paper, Number 599.

Geels, F.W. and Schot, J. (2007) Typology of sociotechnical transition pathways. Research Policy, 36, 3, 399-417.

Geng, Y., Xinbei, W., Qinghua, Z. and Hengxin, Z. (2010) Regional initiatives on promoting cleaner production in China: a case of Liaoning. Journal of Cleaner Production, 18, 15, 1502-1508.

Gibbs, D. and Deutz, P. (2007) Reflections on implementing industrial ecology through eco-industrial park development. Journal of Cleaner Production, 15, 17, 16831695.

Government, H.M. (2015a) Building a high value bioeconomy: Opportunities from waste. London: Crown Copyright.

Government, H.M. (2015b) Local councils and services webpage. Available from: https://www.gov.uk/browse/housing-local-services [Accessed: December 2015]

Government, H.M. (2015c) LEP network. Available from: http://www.lepnetwork.net/about-leps/ [Accessed: December 2015]

Government, H.M. (2015d) GOV.UK. Available from: https://www.gov.uk/government/organisations/environment-agency/servicesinformation [Accessed: December 2015]

Government, H.M. (2014) Government Response to the House of Lords Science and Technology Committee Report: 'Waste or Resource? Stimulating a bioeconomy'. London: Crown Copyright.

Government, H.M. (2011) Skills for a green economy. London: Crown Copyright.

Government, H.M. (2009) The UK Low Carbon Transition Plan: National strategy for climate and energy. London: Crown Copyright. 
HCF-Catch (2015) Humber Chemical Focus Catch website. Available from: http://hcfcatch.com/ [Accessed: December 2015]

Hoffman, A.J., Corbett, C.J., Joglekar, N. and Wells, P. (2014) Industrial Ecology as a Source of Competitive Advantage. Journal of Industrial Ecology, Special feature on industrial ecoloy as a source of competitive advantage, 18, 5, 1-6.

Hollstein, B. (2011) Qualitative Approaches. In J. Scott and P. J. Carrington (eds) Sage Handbook of Social Network Analysis. London/New Delhi: Sage.

Humber Local Enterprise Partnership (2014) Strategic Economic Plan 2014-2020. Hull: Humber Local Enterprise Partnership.

IPCC (2014) Climate Change 2014: Synthesis report. Geneva: Intergovernmental Panel on Climate Change.

Jensen, P.D. (2016) The Role of Geospatial Industrial Diversity in the Facilitation of Regional Industrial Symbiosis. Resources, Conservation and Recycling, 107: 92 103.

Jensen, P. D., Basson, L., Hellawell, E.E. and Leach, M. (2012) Habitat' Suitability Index Mapping for Industrial Symbiosis Planning. Journal of Industrial Ecology, 16, 1, 38-50.

Jensen, P.D., Basson, L., Hellawell, E.E., Bailey, M.R. and Leach, M. (2011) Quantifying 'geographic proximity': Experiences from the United Kingdom's National Industrial Symbiosis Programme. Resources Conservation and Recycling, 55, 7, 703-712.

Jiao, W. and Boons, F. (2014) Toward a research agenda for policy intervention and facilitation to enhance industrial symbiosis based on a comprehensive literature review. Journal of Cleaner Production, 67, 14-25.

Jones, S. (2004) Chapter 37 Depth interviewing, In: C. Seale (ed.) Social research methods: A reader. London: Routledge.

Koskela, S., Matilla, T., Antikainen, R. and Mäenpää, I. (2013) Identifying Key Sectors and Measures for a Transition towards a Low Resource Economy. Resources, 2, 151-166.

Laybourn, P. and Clark, W. (2004) National Industrial Symbiosis Programme: A year of achievement. Blackheath: UK Business Council for Sustainable Development.

Laybourn, P. and Morrissey, M. (2009) National Industrial Symbiosis Programme: The Pathway To A Low Carbon Sustainable Economy. Kings Norton, UK: International Synergies Ltd.

Lee, B., Preston, F., Kooroshy, J., Bailey, R. and Lahn, G. (2012) Resources Futures: A Chatham House Report. London: The Royal Institute of International Affairs.

Lehtoranta, S., Nissinen, A., Mattila, T. and Melanen, M. (2011) Industrial symbiosis and the policy instruments of sustainable consumption and production. Journal of Cleaner Production, 19, 16, 1865-1875.

LGA (2014) Future funding outlook 2014: Funding outlook for councils to 2019/20. London: Local Government Association.

Lin, C.S.K., Pfaltzgraff, L.A., Herrero-Davila, L., Mubofu, E.B., Abderrahim, S., Clark, J.H., Koutinas, A.A., Kopsahelis, N., Stamatelatou, K., Dickson, F., Thankappan, S., Mohamed, Z., Brocklesby, R. and Luque, R. (2013) Food waste as a valuable resource for the production of chemicals, materials and fuels. Current situation and global perspective. Energy \& Environmental science, 6, 426-464.

Lundvall, B.-Å., Johnson, B., Andersen, E.S. and Dalum, B. (2002) National systems of production, innovation and competence building. Research Policy, 31, 2, 213231.

Mason, J. (2002) Qualitative researching, second edition. London: SAGE Publications Ltd.

Material Security Working Group (2015) An Office for Resource Management.

Mathews, J.A. and Tan, H. (2011) Progress Toward a Circular Economy in China. Journal of Industrial Ecology, 15, 3, 435-457. 
Mirata, M. (2004) Experiences from early stages of a national industrial symbiosis programme in the UK: determinants and coordination challenges. Journal of Cleaner Production, 12, 8-10, 967-983.

Morgan, J. (2014) The Great Resource Price Shock. London: Green Alliance.

NAO (2014) The impact of funding reductions on local authorities. London: National Audit Office.

NOMIS (2015) UK business counts - enterprises. Edited by ONS.

OECD (2009) The bioeconomy to 2030: Designing a policy agenda. Paris: OECD Publishing.

Paquin, R.L. and Howard-Grenville, J. (2012) The Evolution of Facilitated Industrial Symbiosis. Journal of Industrial Ecology, 16, 1, 83-93.

Park, H.S., Rene, E.R., Choi, S.M. and Chiu, A.S.F. (2008) Strategies for sustainable development of industrial park in Ulsan, South Korea-From spontaneous evolution to systematic expansion of industrial symbiosis. J Environ Manage, 87, 1, 1-13.

Penn, A.S., Jensen, P.D., Woodward, A., Basson, L., Schiller, F. and Druckman, A. (2014) Sketching a Network Portrait of the Humber Region. Complexity: Special Issue on Complexity and Social Policy.

Rotherham, I.D. (2010) Environment, economy and community: responding to future environmental change with reducing public sector resources. People, Place and Policy Online, 4, 1, 33-37.

Rowney, M. (2014) The Waste Line: Redefining 'waste' and improving resource management policy. London: Institute for Public Policy Research.

Salmi, O., Hukkinen, J., Heino, J., Pajunen, N. and Wierink, M. (2012) Governing the Interplay between Industrial Ecosystems and Environmental Regulation. Journal of Industrial Ecology, 16, 1, 119-128.

Schiller, F., Skeldon, A., Balke, T., Grant, M., Penn, A.S., Basson, L., Jensen, P.D., Gilbert, N., Kalkan, O.D. and Woodward, A. (2014) Defining relevance and finding rules: an agent-based model of biomass use in the Humber area. Advances in Social Simulation, 229: 373-384.

Science and Technology Select Committee (2014) Waste or resource? Stimulating a bioeconomy. London: The Stationery Office Limited.

Scott, J. (2000) Social Network Analysis, a handbook. Second ed. London: SAGE Publications Ltd.

Shi, H., Chertow, M. and Song, Y. (2010) Developing country experience with ecoindustrial parks: a case study of the Tianjin Economic-Technological Development Area in China. Journal of Cleaner Production, 18, 3, 191-199.

Shi, L., Guoguo, L. and Siping, G. (2012) International comparison and policy recommendation on the development model of industrial symbiosis in China. Beijing: State Environmental Protection Key Laboratory of Eco-industry, School of Environment, Tsinghua University.

Tödtling, F. and Trippl, M. (2005) One size fits all?: Towards a differentiated regional innovation policy approach. Research Policy, 34, 8, 1203-1219.

UKTI (2009) Chemicals - the UK advantage. London: UK Trade \& Investment.

UNEP (2011) Decoupling: natural resource use and environmental impacts from economic growth. A Report of the Working Group on Decoupling to the International Resource Panel: Fischer-Kowalski, M., Swilling, M., von Weizsäcker, E.U., Ren, Y., Moriguchi, Y., Crane, W., Krausmann, F., Eisenmenger, N., Giljum, S., Hennicke, P., Romero Lankao, P., Siriban Manalang, A., Sewerin, S.

University of Hull (2015) University of Hull website. http://www2.hull.ac.uk/administration/business/aboutus/ourmission.aspx [Accessed: December 2015] 
van den Bergh, J.C.J.M., Truffer, B. and Kallis, G. (2011) Environmental innovation and societal transitions: Introduction and overview. Environmental Innovation and Societal Transitions, 1, 1, 1-23.

Velenturf, A.P.M. (2015) Promoting industrial symbiosis: Empirical observations of lowcarbon innovations in the Humber region, UK. Journal of Cleaner Production, 128, 116-130.

Velenturf, A.P.M. and Jensen, P.D. (2015) Promoting industrial symbiosis: Using the concept of proximity to explore social network development. Journal of Industrial Ecology.

Velenturf, A.P.M., Jensen, P.D., Schiller, F. and Murphy, R.J. (Forthcoming) Evolution of industrial symbiosis: Harmonising top-down and bottom-up processes. Journal of Cleaner Production.

Wang, Q. (2013) Knowledge transfer to facilitate Industrial Symbiosis: a case study of UK-China collaborators. Hull: University of Hull.

Wells, P., Crowe, M., Gilbertson, J., Gore, T. (2011) A Big Society in Yorkshire and the Humber? People, Place and Policy, 5, 2, 89-106.

While, A. (2013) The greenest government ever? The Coalition Government and lowcarbon policy. People, Place and Policy, 7, 2, 100-106.

WRAP (2015) Waste and Resources Action Programme website. Available from: http://www.wrap.org.uk/ [Accessed: December 2015]

York North Yorkshire and East Riding LEP (2015) Website of the York North Yorkshire and East Riding Local Enterprise Partnership. Available from: http://www.businessinspiredgrowth.com/ [Accessed: December 2015]

Yorkshire and the Humber Regional Committee (2010) Carbon Emissions in the Yorkshire and Humber Region. London: House of Commons.

Zhu, Q., Geng, Y., Sarkis, J. and Lai, K.H. (2014) Barriers to Promoting Eco-Industrial Parks Development in China: Perspectives from Senior Officials at National Industrial Parks. Journal of Industrial Ecology, 19, 3, 457-467.

Zilahy, G. and Milton, S. (2008) The environmental activities of industrial park organisations in Hungary. Progress in Industrial Ecology, 5, 5/6, 422-447. 